\title{
The effects of timolol maleate gel formulation $0.1 \%$ on intraocular pressure and pulse rate in dogs
}

\author{
Michela Pugliese, Monica Ragusa, Pietro Paolo Niutta, \\ and Annamaria Passantino*
}

Department of Veterinary Sciences, Polo Universitario Annunziata, University of Messina, Messina, Italy

\begin{abstract}
PUGliese, M., M. RAGUSA, P. P. NiUTta, A. PASSANTINO: The effects of timolol maleate gel formulation $0.1 \%$ on intraocular pressure and pulse rate in dogs. Vet. arhiv 88, 335-343, 2018.
\end{abstract}

\section{ABSTRACT}

The objectives of new topical formulations for the treatment of glaucoma are to reduce the intraocular pressure (IOP) and minimize the occurrence of side effects. The aim of this study was to determine the effects of topical application of timolol maleate gel formulation $0.1 \%$ applied once daily, on the intraocular pressure and pulse rate (PR) in ten healthy dogs. A clinical blinded trial was performed over two different periods; each period was divided into a pretreatment phase (D0) and four days of treatment (D1-4), with a wash out period of 10 days. Treatments consisted of administration of one drop of timolol $0.1 \%$ gel formulation once a day and artificial tears. The IOP and PR values were recorded in all animals five times daily (7:00 AM, 10:00 AM, 1:00 PM, 5:00 PM, and 9:00 PM). Adverse events (conjunctival hyperemia, discomfort, breathing, and allergic reaction) were documented. Compared with the placebo treatment, the topical treatment with timolol gel formulation resulted in a significant decrease in IOP and PR. Already 24 hours after administration, TMG induced a significant reduction in IOP. In the group treated with TMG the mean decrease in IOP was $3.4 \mathrm{~mm}$ $\mathrm{Hg}(\mathrm{P}<0.01)$, the mean decrease in $\mathrm{PR}$ was $10.8(\mathrm{P}<0.01)$. Topical administration of timolol maleate gel $0.1 \%$ formula was effective in lowering IOP in healthy dogs. The gel formulation improves bioavailability, but it seems there was no reduction in adverse cardiopulmonary effects.

Key words: beta blockers; timolol; dog; pulse rate; intraocular pressure

\section{Introduction}

Glaucoma is actually considered to be a group of diseases, associated with retinal ganglion cell (RGC) death (OSBORNE et al., 2016). The principal risk factor related to glaucoma is the elevation of intraocular pressure (IOP), resulting in loss of vision by destruction of ocular structures. So, the treatment mainly aims at reducing intraocular

\footnotetext{
${ }^{*}$ Corresponding author:

Prof. Annamaria Passantino, DVM, PhD, Dipl. ECAWBM (AWSEL), Department of Veterinary Sciences, Polo Universitario Annunziata, University of Messina, 98168, Messina, Italy, Phone: +39 90350 3742; Fax: +39 90350 3614; E-mail: passanna@unime.it
} 
pressure, in order to maintain the integrity of the optic nerve. Beta adrenergic antagonists such as timolol are ocular hypotensive agents, widely used for treatment of glaucoma in humans and dogs, and they decrease the production of aqueous humor (REALINI, 2011; CONLON et al., 2017). In general the side effects are reported of beta-blockers in the eye drops on the cardiovascular and respiratory systems (MAENPAA and PELKONEN, 2016).

In order to overcome the limitations related to the administration of eye drops, recent studies have developed a new formulation of timolol maleate in gel form, which should ensure the better permeability of the drug. The new formulation in gel form should prolong the residence time in the precorneal region, thereby increasing its therapeutic effects.

This study aimed to determine the potential therapeutic effects of timolol maleate gel formulation $0.1 \%$ on reducing intraocular pressure and to monitor the side effects on the cardiovascular system in healthy dogs.

\section{Materials and methods}

Animals. A total of 10 owned and healthy, mixed-breed dogs (3 intact males, 7 intact females), between 12 and 18 months old (median age 14 months; SD 2.26), weighing 6-9 $\mathrm{Kg}$ (median weight: $7 \mathrm{~kg}$ ) were included in the study. The dogs' main characteristics are summarized in Table 1. All subjects were defined as healthy after a complete physical examination and an electrocardiogram, including a record of heart rate. None of dogs had signs of ocular disease, as determined by complete ophthalmic examination, including a Schirmer tear test (STT), fluorescein staining, slit-lamp biomicroscopy, applanation tonometry, gonioscopy and dilated fundus examination.

Table 1. Dogs' main characteristics

\begin{tabular}{|l|c|}
\hline Total & 10 \\
\hline Age (median) & 14 months \\
\hline Male (\%) & 30 \\
\hline Female (\%) & 70 \\
\hline Weigh (median) & $7 \mathrm{~kg}$ \\
\hline
\end{tabular}

This study was carried in accordance with the ethical principles of the Veterinarians' Ethical Code (PASSANTINO, 2007) - with respect to the high standard of veterinary care and veterinary best practice - and the Italian and European regulations on animal welfare (Directive 2010/63/EU of the European Parliament and of the Council of 22 September 2010 on the protection of animals used for scientific purposes.).

An informed consent form was signed by the owners at the screening visit.

Procedures. The study was performed over two different periods, each of 5 days, divided into a pretreatment phase (D0) and four days of treatment (D1-4). A wash out 
period of 10 days was performed between the two treatments. The dogs were kept in a standard room with a temperature-controlled environment at $21-23^{\circ} \mathrm{C}$ and exposed to an automatic 12-hour light/dark regimen (light phase from 7:00 AM to 7:00 PM. and a dark phase from 7:00 PM to $7 \mathrm{AM}$ ). All dogs received a normal diet given at 12:00 h each day. Water was available ad libitum.

Treatments. In each period, a separate protocol was tested: protocol A consisted of administration of one drop of timolol $0.1 \%$ gel formulation (Timogel, $1 \mathrm{~g} / 1 \mathrm{mg}$, Laboratoires Thea, Clermont-Ferrand, France) (TMG), protocol B of application of one drop of artificial tears (Blu Sal ${ }^{\circledR}$, Sooft, Italy) as a placebo (PB). All treatments were performed by the same observer (A.P.) every 24 hours (8:00 AM) on both eyes. The observer was blinded to the protocol.

Measurements. The IOP and PR values were recorded in all animals five times daily (7:00 AM, 10:00 AM, 1:00 PM, 5:00 PM, and 9:00 PM). The IOP was recorded by applanation tonometry Tonopen ${ }^{\circledR}$-Vet (Medtronic, FL, USA) by the same operator (M.R.) after administration of a topical anesthetic (Oxybuprocaine Hydrochloride 0.4\%, Novartis Farma, Italy). For measurements of IOP the dogs were sternally recumbent. During restraint, no pressure was applied to the neck.

The mean value of 5 measurements at each time point was used in the calculations. The mean values of the first measurement each day were considered as the baseline values. IOP measurements were repeated when there was an excessive deviation between the 5 measurements displayed by tonometry related to defects of the probe position or misalignment with the central portion of the cornea. The PR was ascertained by a stethoscope placed by the same observer (M.P.) on the chest over the point of maximum heart beat intensity for 60 seconds. Adverse events (conjunctival hyperemia, discomfort, breathing, and allergic reaction) were recorded.

Grading of conjunctival hyperemia was performed with a slit lamp using a standard scale (0-3, where: 0 is none; 1 mild; 2 moderate; and 3 severe). The presence and severity of hyperemia were assessed in several phase IV registration trials (D1-D4) and in both eyes. Allergic reactions (defined as the presence of the following symptoms: hyperemia, blepharospasm, swelling of the eyelid, tearing) were also graded as none, mild, moderate and severe.

Statistical analysis. For each dog, the IOP of both eyes and of the PR were measured. Data are expressed as mean and standard deviation (SD). The non-parametric approach was used since the numerical variables were not normally distributed, as verified by the Kolmogorov Smirnov test. The Friedman test (that is a non-parametric ANOVA for repeated-measures) was applied in order to evaluate possible significant differences in IOP and PR at different times (before treatment and 1,2,3 and 4 days thereafter), for both timolol and placebo. Lastly, the Chi Square Test was used for comparisons of discrete 
variables. Statistical analyses were performed using the SPSS for Window package (Version 17.0, SPSS, Inc., Chicago). $\mathrm{P}<0.05$ two sides was considered to be statistically significant.

\section{Results}

Intraocular pressure. During the pre-treatment phase (D0) a diurnal fluctuation of IOP within the normal ranges was observed (Table 2). Since no significant differences in IOP were detected during this time in any dogs, the baseline values were not considered as covariate and the statistical test was done between the treatments. The mean values of IOP for each day are reported in Table 2. No significant differences were detected within the eyes of the control group. Compared with the placebo treatment, the topical treatment with timolol gel formulation resulted in a significant decrease in IOP and PR (Table 1). The mean decrease in IOP was $3.4 \mathrm{~mm} \mathrm{Hg}(\mathrm{P}<0.01)$ in eyes treated with TMG. At 2 hours after the first administration, the reduction in IOP was $1.8 \mathrm{~mm} \mathrm{Hg}$ in the right eye and $1.4 \mathrm{~mm} \mathrm{Hg}$ in the left. During the treatment with TMG, no significant fluctuations in IOP were seen. The mean SD IOPs measured on day 0 for the timolol group was $16.5 \pm 1.82$ and $16.9 \pm 1.59$ for the protocol group. The mean SD IOPs measured on the last day of the treatment phase (D5) was $13.1 \pm 1.3$ for timolol and $17.6 \pm 1.48$ for the placebo group. On the first day of treatment, highly significant differences were observed between the timolol protocol and the placebo group $(\mathrm{P}<0.01)$. After the end of washout (10 days) IOP returned to pretreatment values. The maximum ocular hypotensive effect was recorded on day 4 for the TMG group (Table 2). The greatest mean SD reduction in IOP was detected at $\mathrm{D} 3$ of treatment in the TMG group.

Table 2. Variations in IOP ( $\mathrm{mmHg})$ and PR (bpm) values during the study for the protocol A (TMG administration) and protocol $\mathrm{B}$ (PB administration) during the pre-treatment phase (D0), day 1 (D1) and during the other days (D2-D4).

\begin{tabular}{|c|c|c|c|c|c|c|c|c|}
\hline \multirow{2}{*}{\multicolumn{2}{|c|}{$\begin{array}{l}\text { Measurement } \\
\text { indices }\end{array}$}} & \multirow{3}{*}{$\begin{array}{l}\text { Baseline } \\
\text { (D0) } \\
16.1 \pm 1.85\end{array}$} & \multirow{3}{*}{$\frac{\mathrm{D} 1}{3.2 \pm 2.29}$} & \multirow{3}{*}{$\frac{\text { D2 }}{13 \pm 1.41}$} & \multirow{3}{*}{$\frac{\text { D3 }}{11.2 \pm 0.63}$} & \multirow{3}{*}{$\frac{\mathrm{D} 4 \mathrm{c}^{2}}{13 \pm 1.24}$} & \multicolumn{2}{|c|}{$\begin{array}{l}\text { Friedman } \\
\text { test }\end{array}$} \\
\hline & & & & & & & \multirow{2}{*}{\begin{tabular}{|c|}
$P$ \\
20.81 \\
\end{tabular}} & \multirow[b]{2}{*}{0.001} \\
\hline \multirow{2}{*}{ IOP-TMG } & od & & & & & & & \\
\hline & os & $16.9 \pm 1.79$ & $14 \pm 1.15$ & $12.6 \pm 1.57$ & $11.2 \pm 0.91$ & $13.2 \pm 1.39$ & 27.30 & 0.001 \\
\hline \multirow{2}{*}{ IOP-PB } & od & $17.4 \pm 0.96$ & $17 \pm 1.69$ & $17.5 \pm 1.58$ & $16.9 \pm 1.66$ & $17.1 \pm 1.37$ & 2.41 & 0.660 \\
\hline & os & $16.5 \pm 1.26$ & $16.3 \pm 1.25$ & $16.5 \pm 1.50$ & $17.3 \pm 1.56$ & $18.1 \pm 1.59$ & 8.05 & 0.089 \\
\hline \multicolumn{2}{|c|}{ PR-TMG (bpm) } & $97 \pm 6.79$ & $76.4 \pm 6.76$ & $88.6 \pm 7.02$ & $86 \pm 7.73$ & $104 \pm 7.19$ & 32.31 & 0.001 \\
\hline \multicolumn{2}{|c|}{ PR-PB (bpm) } & $102 \pm 7.78$ & $93 \pm 3.49$ & $98.5 \pm 5.58$ & $98.5 \pm 5.93$ & $96.3 \pm 9.33$ & 6.39 & 0.171 \\
\hline
\end{tabular}

od $=$ oculus dexter (right eye); $\mathrm{s}=$ oculus sinister (left eye); $1 \mathrm{bpm}=$ beats per minute 
During the treatment with the placebo, variations in IOP were observed, but they were not statistically significant (D1 vs $\mathrm{D} 5, \mathrm{P}=0.37$ ).

Pulse rate. Since no significant differences in PR were observed during the pretreatment phase (D0) in any dogs, the baseline values were not considered as covariate and the statistical test was done between the treatments. The treatment with timolol gel caused a highly significant variation in PR, compared with the group control. The mean values of PR for each day are reported in Table 2. Compared with the placebo treatment, the topical treatment with timolol gel formulation resulted in a significant decrease in PR (Table 1). The mean decrease in PR was $10.8(\mathrm{P}<0.01)$ in the group treated with TMG. The mean SD PRs measured on day 0 were 976.79 for the timolol group and 1027.78 for the protocol (placebo?-english lector) group. The mean SD PRs measured on the second day of treatment phase (D5) were 76.46.76 for the timolol group and 933.49 for the placebo group. On the first day of treatment highly significant differences were observed between the timolol protocol and the placebo groups $(\mathrm{P}<0.01)$. After the end of washout (10 days) PR was normal.

Adverse effects. During the treatment phase, no ocular side effects or signs of discomfort were observed. All animals tolerated the topical medications well. Table 3 shows the trial safety results. Although no severe or moderate local side effects were observed during and at the end of the clinical trial, TMG-treated animals had less conjunctival hyperemia (1/10 vs. 0/10) than patients treated with PB.

Table 3. Local Adverse Events during day 1 (D1) and the other days (D2-D4).

\begin{tabular}{|c|l|c|c|c|c|c|c|c|c|}
\hline \multicolumn{2}{|c|}{} & \multicolumn{4}{c|}{ TMG } & \multicolumn{4}{c|}{ PB } \\
\cline { 2 - 10 } & Normal & Mild & Moderate & Severe & Normal & Mild & Moderate & Severe \\
\hline D1 $\begin{array}{l}\text { Conjunctival } \\
\text { hyperemia }\end{array}$ & 9 & 1 & 0 & 0 & 0 & 0 & 0 & 0 \\
\hline D2 $\begin{array}{l}\text { Conjunctival } \\
\text { hyperemia }\end{array}$ & 9 & 1 & 0 & 0 & 0 & 0 & 0 & 0 \\
\hline D3 $\begin{array}{l}\text { Conjunctival } \\
\text { hyperemia }\end{array}$ & 9 & 1 & 0 & 0 & 0 & 0 & 0 & 0 \\
\hline D4 & $\begin{array}{l}\text { Conjunctival } \\
\text { hyperemia }\end{array}$ & 9 & 1 & 0 & 0 & 0 & 0 & 0 & 0 \\
\hline
\end{tabular}

\section{Discussion}

Timolol maleate is a non-selective beta-adrenergic receptor agent that reduces IOP by reducing the formation of aqueous humor (HOLLÓ et al., 2014). It is useful in the treatment of glaucoma, like other substances belonging to the same class, as it reduces IOP, and thus the damage to the optic nerve (SENA and LINDSLEY, 2013; LEE et al., 2016; MEDEIROS et al., 2016; KONSTAS and HOLLÓ, 2016; LERNER et al., 2017), 
and might protect retinal ganglion cells (VIDAL et al., 2010; SENA and LINDSLEY, 2013). In humans, Beta-blockers are contraindicated in patients with heart failure or bronchial asthma for their potential adverse effects on the cardiovascular and respiratory systems. In veterinary medicine, any authors have observed a reduction in the pulse rate of normotensive and glaucomatous dogs, cats and horses treated with topical timolol at different concentrations, in monotherapy or associated with other drugs (PLUMMER et al., 2006; TAKIYAMA et al., 2006; TOFFLEMIRE et al., 2015; KILAND et al., 2016; MATUSOW et al., 2016).

The purpose of this study was to evaluate the efficacy in reducing IOP in healthy dogs of treatment with a timolol maleate $0.1 \%$ gel formulation, as a pharmacological alternative in the treatment of canine glaucoma. The gel is an anion heteropolysaccaride gellan gum, which gels in contact with the tear fluid allowing an increase in bioavailability.

The use of the gel formulation allows application of the drug only once a day, facilitating therapeutic management and improving compliance by the owner.

This study showed that timolol $0.1 \%$ gel formulation administered once a day is efficient to reduce IOP in dogs just as in humans, but it may be the cause of pulse rate reduction.

The administration of timolol maleate in a gel induced a significant reduction in IOP in the first $24 \mathrm{~h}$, and this effect remained constant during the day, with hourly fluctuations (NUCCI et al., 2013; SEIBOLD et al., 2017). Therefore, further clinical studies in glaucomatous dogs are required. The period of washout between two treatments was considered adequate; the same study design was used in clinical trials on glaucomatous subjects to study the short-term activity of Beta-blockers (SCARDILLO et al., 2010).

In our study only one dog showed mild conjunctival hyperemia after administration of TMG. Side effects such as local intolerance (i.e. stinging, burning), photophobia, ptosis blepharon conjunctivitis and superficial keratitis have been reported after ocular administration of Beta-Blockers in humans (ROMERO-DIAZ DE LEON et al., 2016).

In humans, the hypotensive effects of timolol gel are equivalent to those recorded with the formulation in a solution, applied twice daily, and with a reduction of side effects (KAARNINTA et al., 2016). Indeed, the gel formulation reduced systemic absorption of the drug, resulting in amplification of its effect and less cardiopulmonary side effects.

In conclusion, the authors suggest that timolol maletate $0.1 \%$ gel formulation may potentially be used in the treatment of glaucoma in dogs, but other studies are necessary to evaluate the same efficacy in hypertensive dogs.

\section{Acknowledgements}

The authors thank Caroline Keir for her assistance in revision of the English manuscript.

\section{Conflicts of interest}

None declared 


\section{References}

CONLON, R., H. SAHEB, I. I. K. AHMED (2017): Glaucoma treatment trends: a review. Can. J. Ophthalmol. 52, 114-124.

HOLLÓ, G., J. VUORINEN, J. TUOMINEN, T. HUTTUNEN, A. ROPO, N. PFEIFFER (2014): Fixed-dose combination of tafluprost and timolol in the treatment of open-angle glaucoma and ocular hypertension: comparison with other fixed-combination products. Adv. Ther. 31, 932-944.

KAARNINTA, K., K. IKAHEIMO, E. MANNERMAA, A. ROPO (2016): Pharamcokinetics, efficacy and safety of the preservative-free fixed combination of tafluprost $0.0015 \%$ and timolol $0.5 \%$ in healthy volunteers: a phase I comparison vs the corresponding preservativefree monotherapies. Clin. Pharmacokinet. 55, 485-494.

KILAND, J. A., A. M. VOSS, G. J. McLELLAN (2016): Effect of timolol maleate gel-forming solution on intraocular pressure, pupil diameter and heart rate in normal and glaucomatous cats. Vet. Ophtalmol. 19, 91-96.

KONSTAS, A. G. P., G. HOLLO (2016): Preservative-fre talfuprost/timolol fixed combination: a new opportunity in the treatment of glaucoma. Expert. Opin. Pharmacother. 17, 1271-1283.

LEE, N. Y., H. Y. PARK, C. K. PARK (2016): Effects of a dorzolamide/timolol fixed combination on diurnal intraocular pressure, heart rate, blood pressure and ocular perfusion pressure in normal tension glaucoma. Jpn. J. Ophtalmol. 60, 377-382.

LERNER, S. F., K. H. PARKER, D. A. HUBATSCH, V. ERICHEV, J. A. PACZKA, T. V. ROBERTS (2017): Efficacy and tolerability of travanaprost $0.004 \%$ Timolol $0.5 \%$ FixedDose combination for the treatment of primary open-angle glaucoma or ocular hypertension inadequately controlled with beta-blocker monotherapy. J. Ophthalmol. 2017, 1-8.

MAENPAA, J., O. PELKONEN (2016): Cardiac safety of ophthalmic timolol. Expert. Opin. Drug. Saf. 15, 1549-1561.

MATUSOW, R. B., J. P. HERRING, J. P. PICKETT, N. HENAO-GUERRERO, S. R. WERRE (2016): Effects of perioperative topical dorzolamide hydrochloride-timolol maleate administration on incidence and severity of postoperative ocular hypertension in dogs undergoing cataract extraction by phacoemeulsification. J. Am. Vet. Med. Assoc. 249, 1040-1052.

MEDEIROS, F. A., K. R. MARTIN, J. PEACE, B. SCASELLATI SFORZOLINI, J. L. VITTITOW, R. N. WEINREB (2016): Comparison of Latanoprestene Bunod $0.024 \%$ and timolol maleate $0.5 \%$ in open-angle glaucoma or ocular hypertension. The lunar study. Am. J. Ophtalmol. 168, 250-259.

NUCCI, C., C. VARESI, A. MARTUCCI, M. CESAREO, R. MANCINO, L. CERULLI (2013): Efficacy of timolol $0.1 \%$ gel and a prostaglandin analog in a unfixed combination compared to the corresponding fixed combinations. Eur. J. Ophtalmol. 23, 883-689.

OSBORNE, N. N., C. NUNEZ-ALVAREZ, B. JOGLAR, S. del OLMO-AGUADO (2016): Glaucoma: focus on mitochondria in relation to pathogenesis and neuroprotection. Eur. J. Pharmacol. 787, 127-133. 
PASSANTINO, A. (2007): Ethical aspects for veterinarians regarding antimicrobial drug use in Italy. Int. J. Antimicrob. Ag. 29, 240-244.

PLUMMER, C. E., E. O. MACKAY, K. N. GELATT (2006): Comparison of the effects of topical administration of a fixed combination of dorzolamide-timolol to monotherapy with timolol or dorzolamide on IOP, pupil size, and heart rate in glacomatous dogs. Vet. Ophtalmol. 9, 245249.

REALINI, T. (2011): A history of glaucoma pharmacology. Optom. Vis. Sci. 88, 36-38.

ROMERO-DIAZ DE LEON, L., J. E. MORALES-LEON, J. LEDESMA-GIL, A. NAVAS (2016): Conjunctival and corneal sensitivity in patients under topical and antiglaucoma treatment. Int. Ophtalmol. 36, 299-303.

SCARDILLO, A., M. PUGLIESE, M. DE MAJO, P. P. NIUTTA, A. PUGLIESE (2010): Effects of topical $0.5 \%$ levobunolol alone or in associatin with $2 \%$ dorzolamide compared with a fixed combination of $0.5 \%$ timolol and $2 \%$ dorzolamide on intraocular pressure and heart rate in dogs without glaucoma. Vet. Ther. 11, 1-6.

SEIBOLD, L. K., P. E. DE WITT, M. E. KROEHL, M. Y. KAHOOK (2017): The 24-hour effects of brinzolamide/brimonidine fixed combination and timolol on intraocular pressure and ocular perfusion pressure. J. Ocul. Pharmalcol. Ther. 33, 161-169.

SENA, D. F., K. LINDSLEY (2013): Neuroprotection for treatment of glaucoma in adults. Cochrane Db. Syst. Rev. 25, 1.

TAKIYAMA, N., S. SHOJI, I. HABATA, S. OHBA (2006): The effects of a timolol maleate gel forming solution on normotensive beagle dogs. J. Vet. Med. Sci. 68, 631-633.

TOFLEMIRE, K. L., E. M. WHITLEY, A. M. FLINN, V. L. DUFOUR, G. BEN-SHLOMO, R. A. ALBAUGH, A. N. GRIGGS, C. S. PETERSON, D. R. WHITLEY (2015): Effect of topical ophthalmic dorzolamide (2\%)- timolol $(0.5 \%)$ solution and ointment on intraocular pressure in normal horses. Vet. Ophtalmol. 18, 457-461.

VIDAL, L., F. DIAZ, A. VILLENA, M. MORENO, J. G. CAMPOS, I, PEREZ DE VARGAS (2010): Reaction of Muller cells in an experimental rat model of increased intraocular pressure following timolol, latanoprost and brimonidine. Brain. Res. Bull. 82, 18-24.

Received: 30 April 2017

Accepted: 24 November 2017

PUGliese, M., M. RAgUSA, P. P. NIUTta, A. PASSANTINO: Učinci 0,1 $\%$-tne formulacije timolol-maleat gela na intraokularni tlak i puls u pasa. Vet. arhiv 88, 335-343, 2018.

\section{SAŽETAK}

Cilj novih lokalnih formulacija za liječenje glaukoma jest smanjiti intraokularni tlak (IOP) i nuspojave. Ovim su se istraživanjem željeli utvrditi učinci lokalne primjene $0,1 \%$-tne formulacije timolol-maleat gela (TMG), jedanput dnevno, na intraokularni tlak i puls (PR) u deset zdravih pasa. Jednostruko slijepo kliničko istraživanje obavljeno je u dva različita razdoblja. Svako je razdoblje podijeljeno u fazu predobrade (D0) i četiri dana obrade (D1-4) s ispiranjem od 10 dana. Obrade su se sastojale od kapanja jedne kapi $0,1 \%$-tne formulacije 
timolol-gela jedanput dnevno i umjetnih suza. Vrijednosti IOP-a i PR-a utvrđene su kod svih životinja pet puta dnevno ( $7.00 \mathrm{~h}, 10.00 \mathrm{~h}, 13.00 \mathrm{~h}, 17.00 \mathrm{~h}$ i $21.00 \mathrm{~h}$ ). Zabilježene su nuspojave (konjunktivalna hiperemija, nelagoda, disanje i alergijska reakcija). U usporedbi s placebo-obradom, topikalna terapija s formulacijom timolol-gela rezultirala je značajnim smanjenjem IOP-a i PR-a. Samo 24 sata nakon primjene TMG je izazvao značajno smanjenje IOP-a. U skupini koja je liječena TMG-om srednja vrijednost sniženja IOP-a bila je 3,4 $\mathrm{mmHg}(\mathrm{P}<0,01)$, a prosječno sniženje $\mathrm{PR}-\mathrm{a}$ iznosilo je $10,8(\mathrm{P}<0,01)$. Zaključno, topikalna primjena 0,1 \%-tne formulacije timolol-maleat gela bila je učinkovita u snižavanju IOP-a u zdravih pasa. Formulacija gela poboljšava biološku korisnost, ali čini se da ne smanjuje kardiopulmonalne štetne učinke.

Ključne riječi: beta-blokatori; timolol; pas; puls; intraokularni tlak 
